\title{
REDUCTION OF NITROUS OXIDE CONTAMINATION IN A PAEDIATRIC HOSPITAL
}

\author{
Richard M.M. Flowerdew and WILLiam M. Brummitt
}

ANAESTHETIC agents can cause acute 1.2 and chronic ${ }^{3.4}$ illness in operating-room personnel and contribute to atmospheric pollution in hospitals. ${ }^{9}$ Several professional ${ }^{3-5}$ and national ${ }^{6-8}$ bodies have proposed guidelines concerning this problem.

We examined the concentrations of nitrous oxide in operating-room areas at The Hospital for Sick Children, Toronto, before and after attaching scavenging devices to a Jackson Rees modification of Ayre's T-piece. This delivery system is widely used in paediatric anaesthetic practice. Because of necessarily high fresh gas flows it has a great potential for contamination.

\section{Materials and Methods}

Nitrous oxide concentrations were measured with an infrared trace-gas analyzer (Ohio Medical Products. Madison. Ohio. U.S.A.). This apparatus uses the $4.5 \mathrm{~mm}$ wavelength absorptionspectrum band and a sampling cell $5.5 \mathrm{~m}$ long, to provide high specificity. The response is rapid and is accurate to within 0.5. Measurements are recorded on two scales, showing 0 to 25 p.p.m. and 0 to 250 p.p.m.; the minimal detectable concentration is <1 p.p.m. Each measurement was taken after the scale became stable.

The operating rooms are typical in layout and have usual furnishings (Figure 1). Each room is ventilated by a non-recirculating air-conditioning system that provides 10 room-air changes per hour. Fresh air enters through four ceilingmounted diffusers and is exhausted through one floor duct and one ceiling duct. Anaesthetic gases are scavenged through the surgical vacuum system, at a flow-rate of 30 litres per minute and are exhausted outside the building. The corridors are

Richard M.M. Flowerdew, M.D., F.F.A.R.C.S., Formerly Fellow in Anaesthesia, The Hospital for Sick Children. Toronto; now Assistant Clinical Professor. Tufts University School of Medicine, and Staff Anesthetist, Maine Medical Center. Portland, Maine. William M. Brummitt, M.D., F.R.C.P. (C). Associate Professor. University of Toronto and Staff Anaesthet ist. The Hospital for Sick Children, Toronto.

Mailing address: Dr. R.M.M. Flowerdew, Department of Anesthesia, Maine Medical Center, Tufts University School of Medicine, Portland. Maine, U.S.A. 370

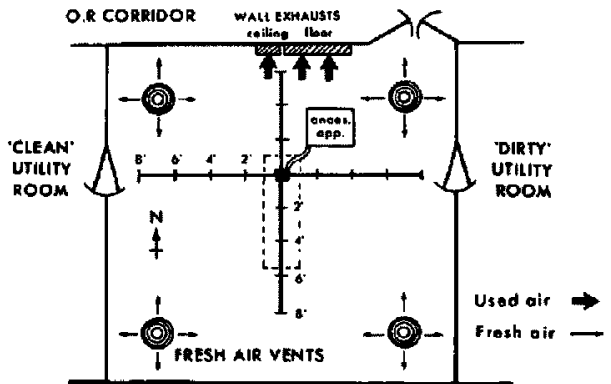

FIGURE I Floor plan of representative operating room: volume, $3.600 \mathrm{cu}$. $\mathrm{ft}$; room-air changes (nonrecirculating), $10 \mathrm{per}$ hr. The square at the intersection of the axes represents the area of gas de livery (patient's head) on the operating table.

ventilated by outflow of the higher-pressure air in the operating rooms. The post-anaesthesia recovery room has a non-recirculating ventilation system which provides 15 to 20 room-air changes per hour.

In the majority of paediatric patients, fluctuations due to tidal respiration are dampened by the high gas flow, reservoir capacity, rapid rate and small tidai volumes. Therefore, in our experiments, the release of gases from the anaesthetic system at the head of the operating table (see Figure 1) was deemed continuous. During observations within operating rooms all doors were kept closed and the observer's movements were minimal.

\section{EXPERIMENTS}

We first validated the experimental design by measuring the steady-state nitrous oxide concentrations at one point (west $8^{\prime}$ in Figure 1) at five flow-rates, to determine dilution by the airconditioning at that point. Then we conducted eight experiments designed to show nitrous oxide concentrations encountered by anaesthetists and other operating-room personnel under ordinary working conditions.

Single nitrous oxide concentrations were recorded at each of the sites indicated in Figure 1, under six sets of circumstances: during the first two sets samples were taken near the floor

Canad. Anaesth. Soc. J., vol. 26, no. 5, September 1979 
exhaust-grill. (This site was selected as that most likely to give the highest concentration and to provide the most suitable reference point for comparative studies.) Unless otherwise stated only single measurements were made at each site.

1. The basal nitrous oxide concentration was recorded, with cylinders off. pipelines disconnected, and a lapse of at least one hour since use of the room.

2. High-pressure pipelines were opened, cylinders were turned on, and nitrous oxide levels were recorded with the flowmeters off.

For all later experiments the analyzer was five feet above the floor; the level of personnel respiratory exposure.

3. Increases in concentration were measured with nitrous oxide flows of two litres and five litres per minute, at site south 8 .

4. Declines in concentration with the two flow-rates were measured at five-minute intervals after the nitrous oxide had been turned off, at site north 2.

5. Steady-state levels of nitrous oxide for the two flow-rates were measured at fixed points along the axes from the source.

6. Experiment number three was repeated, using various methods of scavenging.

(a) Commercial ventilator (Air Shields. U.S.A.). The entire apparatus was encased in a large plastic bag. which was evacuated by the vacuum scavenge suction.

(b) "Steward box". 12 The reservoir bag was enclosed in a rigid plastic box, with suction flowing through it.

(c) Co-axial reservoir suction scavenger. ${ }^{13}$ The apparatus was attached to the exhalation tail of the anaesthetic reservoir bag.

7. In two further sets of measurements, nitrous oxide concentrations were recorded in the corridors of the operating room suite during a normal working day: (a) with and (b) without scavenging in nearby operating rooms; and (c) when nearby operating rooms were not in use.

8. Nitrous oxide concentrations were recorded in the post-anaesthetic recovery room during a normal working day.

\section{RESULTS}

In the validation study, the accuracy of the nitrous oxide analyzer was established by plotting nitrous oxide concentrations at five flow rates at one site. Straight line correlation $(0.998)$ indicated good agreement between nitrous oxide flows and measured concentrations (Figure 2).

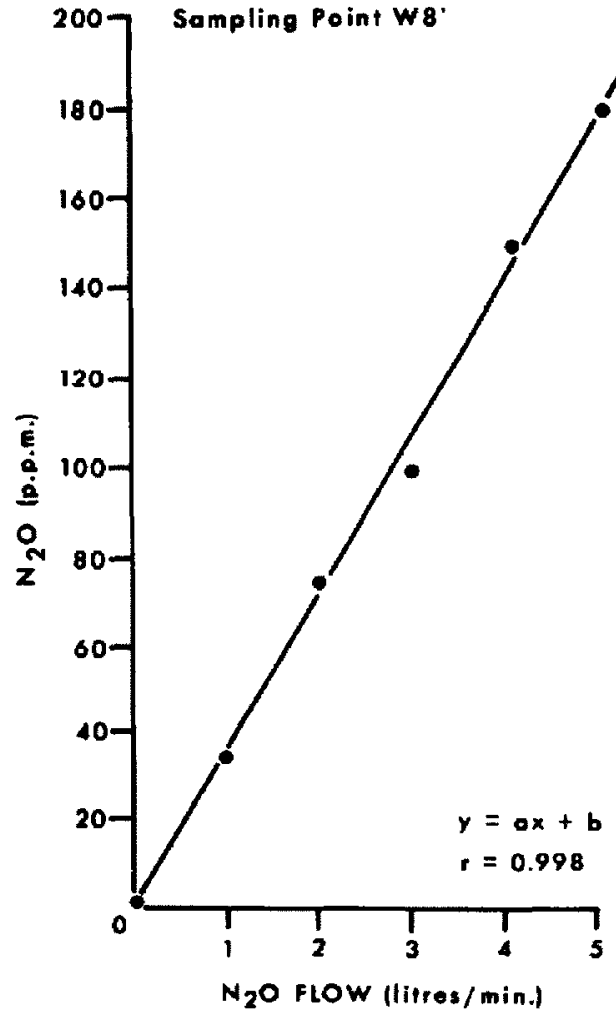

Figure 2 Correlation of nitrous oxide concentrations, se1 and measured, at five flow-rates.

Average basal nitrous oxide level in the 21 operating rooms was 0.86 p.p.m. (Table 1 ). With pipelines connected and cylinders turned on, the high-pressure leak of nitrous oxide average 2.63 p.p.m. Leaks were noted at cylinder heads and pipeline connectors.

Figure 3 illustrates a typical rate of increase in nitrous oxide concentration at two gas flows at a measuring point farthest from the exhaust ducts: even with the lesser flow-rate, the recommended maximal concentration was exceeded within five minutes. At site north 2' (where the anaesthetist would stand), clearance to the recommended maximum took nine minutes with the 2-litre nitrous oxide flow-rate and 13 minutes with the 5-litre flow per minute (Figure 4).

At a flow-rate of five litres per minute steadystate concentrations of nitrous oxide exceeded 250 p.p.m. in all but the most distal parts of the room (Figure 5). At a 2 -litre flow, the concentration at the head of the table exceeded 250 p.p.m. 
TABLE I

Nitrous OXIDE CONCENTRATIONS RECORDED IN 21 OPERATING ROOMS

\begin{tabular}{ccc}
\hline $\begin{array}{c}\text { Pressure } \\
\text { Level }\end{array}$ & $\begin{array}{c}\text { No. of } \\
\text { room: }\end{array}$ & $\begin{array}{c}\text { Nitrous Oxide } \\
\text { (p.p.m.) }\end{array}$ \\
\hline Basal & 10 & $<1.0$ \\
" & 10 & $1.0-1.5$ \\
& 1 & $1.5-2.0$ \\
Average 0.86 \\
High & 4 & $<1.0$ \\
" & 9 & $1.0-1.5$ \\
" & 2 & $1.5-2.0$ \\
" & 1 & $2.0-2.5$ \\
& 5 & $6.0-12.0$ \\
& & Avergge 2.63
\end{tabular}

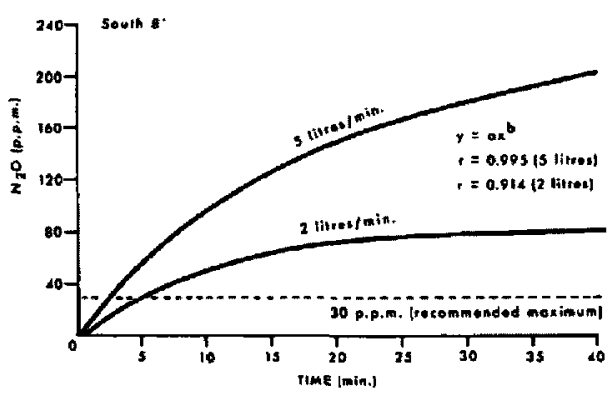

FIGURE 3 Build-up curves of nitrous oxide at site south $8^{\prime}$ (most distant site); no scavenging operative.

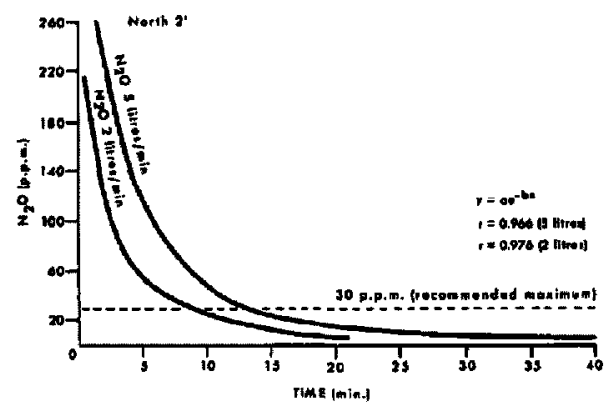

FIGURE 4 Clearance of nitrous oxide from site north 2' (anaesthetist's position); no scavenging.

and even the lowest concentration was almost double the recommended maximum.

Scavenging greatly reduced nitrous oxide concentration (Figure 6). Use of the Steward box or a co-axial scavenger resulted in concentrations that were highest near the exits but even there did not exceed 30 p.p.m. The plastic-enclosed ven* tilator was slightly less effective.

In the corridors within the main operating.

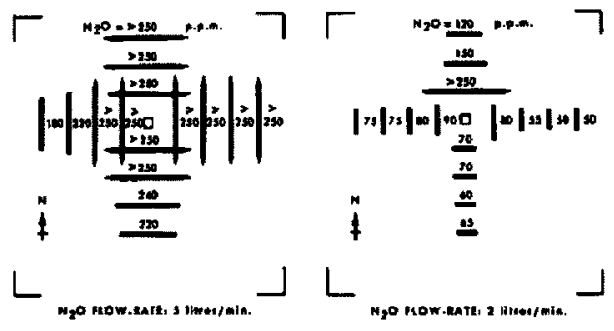

FIGURE 5 Nitsous oxide concentrations at all sites of measurement in the operating room; no scavenging. Bar sizes are proportional to concentration.

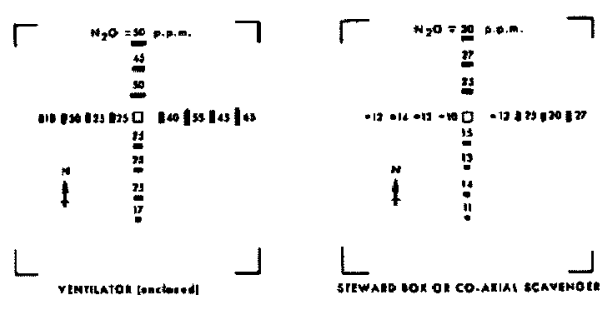

Ficure 6 Nitrous oxide concentrations (p.p.m.) recorded in an operating room; bar sizes are proportional to concentration. Gas flow (per minute) nitrous oxide 5 litres with oxygen 2.5 litres added to simulate a normal scavenging load. Scavenger suction was set at 30 litres per minute.

room suite, measured concentrations varied with nitrous oxide release in the operating rooms. Scavenging noticeably reduced nitrous oxide levels in adjacent corridors (Table II). Peak concentrations were observed coincident with induction of anaesthesia with an open system.

Nitrous oxide contamination in the postanaesthetic recovery room related to the number of patients and their placement in the room (Figure 7). Most commonly, patients were placed close to the nurses' station and the highest concentrations were recorded there.

\section{Discussion}

In 1977 the U.S. National Institute for Occupational Safety and Health (NIOSH) published a comprehensive summary ${ }^{10}$ of the evidence concerning acute and chronic hazards to health from anaesthetic agents or their metabolites. ${ }^{14.15}$ The evidence suggests that such agents carry both short-term and long-term risks. Although it has not been proved that decreasing the concentration of waste gases reduces these hazards, is is prudent to do so.

Achievement of the standards recommended by NIOSH requires a multi-specialty approach. 
TABLE II

Nitrous Oxide Concentrations Recorded in Corktdors Witunn the Main Operating RoOM SUITE

\begin{tabular}{lcc}
\hline \hline & $\begin{array}{c}\text { No. of } \\
\text { analyser } \\
\text { sites }\end{array}$ & $\begin{array}{c}\text { Average } \mathrm{N}_{2} \mathrm{O} \\
\text { concentration } \\
\text { (p.p.m.) }\end{array}$ \\
\hline Basal rate; adjacent operating rooms unoccupied & 10 & 4.7 \\
Adjacent operating rooms in use, without scavenging & 8 & 37.0 \\
Adjacent operating rooms in use, with scavenging & 5 & 8.8 \\
\hline
\end{tabular}

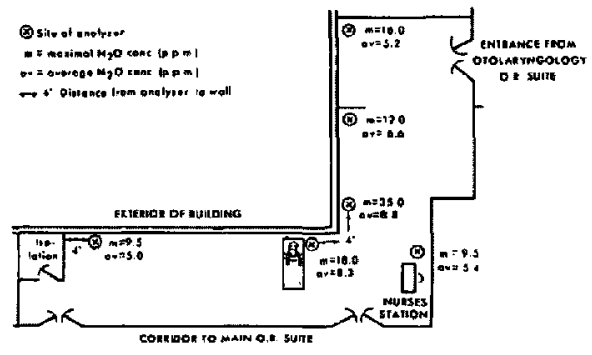

Figure 7 Nitrous oxide concentrations (p.p.m.) recorded in the postanaesthesia recovery room; $n=10$ at each sile. There is no scavenger system. Air-change occurs, 15-20 times per $\mathrm{hr}$, through multiple ceiling diffuser's.

The design of new operating rooms should include provisions for air-conditioning, optimal siting of anaesthetic outlets and equipment and suitable ducting for scavenging equipment. Proper design and regular maintenance of equipment and scavenging of gases is the ideal solution. Various authorities ${ }^{4-8}$ have outlined criteria for maintenance. However, despite careful attention to these factors, high-pressure nitrous oxide leaks exceeded the NIOSH-recommended minimum ( 5 p.p.m.) in five of 21 unused operating rooms. Low-pressure leaks around anaesthetic machines are extremely common; they should be checked for frequently and corrected immediately.

With low or moderate flows of gas, the nitrous oxide concentrations in our operating room rose rapidly above the recommended level of 30 p.p.m. and cleared slowly. In practice. nitrous oxide flows often exceed five litres per minute, particularly at induction of anaesthesia. Open induction is widely used in paediatrics. The rate of build-up and clearance shows that open flows during induction should be as brief as possible and scavenging should be instituted as soon as practicable.

We have demonstrated that nitrous oxide con- tamination in operating rooms and adjacent areas can be reduced to acceptable levels by the application of simple, inexpensive, easily operated scavenging systems. (Our use of a plastic bag over a ventilator was a temporary measure, pending permanent modification of the ventilator.) In the post-anaesthetic recovery room where nitrous oxide concentrations were relatively low and patients constituted the main source of contamination, protection of personnel from anaesthetic gases will depend mainly on the flow-rate of air-conditioning or efficiency of ventilation. Designs for new post-anaesthetic recovery rooms should take into account the need for additional air exhausts in areas with heavy acute patient loads (for example, after otolaryngology procedures) and at the site of the nurses' station. In established recovery rooms, where major alterations cannot readily be achieved, optimal positioning of the nursing station in relation to air-flow patterns may significantly reduce personnel exposure to anaesthetic gases.

\section{SUMMARY}

Ambient nitrous oxide concentrations were recorded in an operating room during delivery of the gas at low and medium flow-rates, with and without the application of simple scavenging devices. Residual background levels of nitrous oxide were still present more than one hour after disconnection of the flowmeters and use of the room. Scavenging reduced concentrations tenfold. Adjacent corridors and the post-anuesthetic recovery room were contaminated with nitrous oxide from the operating rooms and from patients. A vigorous programme of checking for leaks and repairing and maintaining equipment. coupled with the use of suction scavenging, can reduce atmospheric contamination with nitrous oxide below 30 p.p.m., which is well within the limit suggested by the U.S. National Institute for Occupational Safety and Health. 
RÉSUMÉ

Nous avon mesuré les concentrations de protoxyde d'azote dans l'atmosphère de nos salles d'opération au cours d'anesthésies à débits gazeux bas et moyens et, ceci. avec ou sans systèmes de vidange. Des taux résiduels de protoxyde étaient encore présents dans les salles une heure après la fermeture des dëbitmètres et la fin de l'intervention. Les concentrations observées étaient dix fois moindres lorsqu'on utilisait un système de vidange.

Les corridors adjacents aux salles d'opération et les salles de réveil étaient également contaminés par voisinage et par l'exhalation des patients. Un programme agressif de vérification des fuites gazeuses et de réparation, de vérification de l'équipement et des tubulures, associè à une vidange par succion permet de réduire la contamination atmosphérique en protoxyde à une concentration bien inférieure à 30 p.p.m. qui est la limite supérieure suggérée par le National Institute for Occupational Safety and Health aux Etats-Unis.

\section{ACKNOWLEDGEMENTS}

The authors are grateful to staff at The Hospital for Sick Children - to the anaesthesia and engineering staff for their support and encouragement, to Medical Publications for help with this report and to Mrs. Patricia A. Bolduc and Mrs. Sheree A. Sabadin for typing the manuscript; and to the audio-visual staff. Maine Medical Center, who produced the original drawings.

\section{REFERENCES}

1. Bruce. D.L., Bach, M.J. \& Arbit, J. Trace anesthetic effects of perceptual, cognitive and motor skills. Anesthesiology $40 ; 453$ (1974).

2. Bruce, D.L. \& BACH. M.J. Effects of trace concentrations of anesthetic gases on behavioral performance of operating-room personnel. Washington. D.C.. U.S. Govt Printing Office. HEW Publ. no. (NIOSH) 76-169 (1976).

3. American Society of Anesthesiologists, ad hoc committee on the effect of trace anesthetics on the health of operating-room personnel (E.N. Cohen.
Chairman): Occupational disease among operating-room personnel: A national study. Anesthesiology 41: 321 (1974).

4. Cohen, E.N., Brown, B.W., Jr., Bruce, D.L.. Cascorbi, H.F. CORBETt, T.H., Jones. T.W. \& WhITCHER, C.E. A survey of anesthetic health hazards among dentists. J. Am. Dent. Assoc. 90: 1291 (1975).

5. VICKERS, M.D. Pollution of the atmosphere of operating theatres. Advice to members from the Council of the Association of Anaesthetists of Great Britain and Ireland. Anaesthesitl 30:697 (1975).

6. Sweden Labour Protection Board. Narcosis specifications for the protection of personnel against health risks through exposure to gaseous anaesthetics in patient care work [in Swedish]. Stockholm, Sweden, report no. 102 (1975).

7. Subgroup for Evacuation of Anaesthesia Gases, Hospital Engineering Co-operative Group. Recommendation for arrangements against pollution by anaesthesia gases in operating rooms, recovery rooms, and similarly equipped rooms, anaesthesia Division II KAS Gentofte, Copenhagen (1974, unpublished report).

8. Pollution of Operating Departments etc. by Anaesthetic Gases, [D.H.H.S. (England) HC (76) 38] July (1976).

9. FINK, B.R.\& CULLEN, B.F. Anesthetic pollution. What is happening to us? Anesthesiology 45: 79 (1976).

10. Criteria for a Recommended Standard: Occupational exposure to waste anesthetic gases and vapors. Washington, D.C.. U.S. Govt Printing Office. DHEW (NIOSH) Publ. no. 77-140 (1977).

11. Whitcher, C., Piziali, R., Sher, R. \& Moffat, R.J. Development and evaluation of methods for the elimination of waste anesthetic gases and vapors in hospitals. Washington. D.C., U.S. Giovt Printing Office, HEW Publ. no. (NIOSH) 75-137 (1975).

12. Steward, D.J. An anti-pollution device for use with the Jackson Rees modification of Ayre's Tpiece. Can Anaesth. Soc. 1. 19:670 (1972).

13. Floweroew, R.M.M. Coaxial Scavenger for Paediatric Anaesthesia. Can. Anaes. Soc. J, 26: 367 (1979)

14. Stevens, W.C., Eger, E.I., II, White, A.. Biava, C.G., Gibbons, R.D. SHargel. R. Comparative toxicities of enflurane, fluroxene and nitrous oxide at subanaesthetic concentrations in laboratory animals. Can. Anaesth. Soc. J. 24: 479 (1977).

15. Mukal, S., Morio, M., Fujil, K. \& Hanaki, C. Volatile metabolites of halothane in the rabbit. Anesthesiology 47: 248 (1977). 